\title{
Effect of Dehydrated Bovine Colostrum upon Immunity and Development of Dorper Lambs
}

\author{
Fernando Arellano-Rodríguez¹, Josefina Lopez-Hernandez¹, Zurisaday Santos-Jiménez ${ }^{1,2}$, \\ Oscar Ángel-Garcia1', Dalia I. Carrillo-Moreno", Viridiana Contreras-Villarreal ${ }^{1}$, \\ Leticia R. Gaytán-Alemán', Evaristo Carrillo-Castellanos ${ }^{3}$, Juan M. Guillén-Muñoz ${ }^{1}$
}

10.18805/IJAR.BF-1446

\begin{abstract}
Background: Ruminants, during the newborn stage, are considered as agammaglobulinemic (calves and buffalos) or hypogammaglobulinemic (kids and lambs), where the colostrum intake is important for the decrease of illness incidence, an adequate development and a low peripartum mortality. The aim was to evaluate the use of dehydrated bovine colostrum as an alternative to natural ovine colostrum upon de development and immunity of Dorper lambs.

Methods: A total of 35 lambs, divided in two groups, one $(\mathrm{CN} ; \mathrm{n}=17)$ fed with natural colostrum directly from the mother, the second $(\mathrm{CB} ; \mathrm{n}=18)$ fed with a colostrum substitute based on dehydrated bovine colostrum, were used.

Result: The colostrum quality was better for the $\mathrm{CN}$ group regarding lipids, $\mathrm{CP}$, density, solids and fat when compared to the $\mathrm{CB}$ $(\mathrm{p}<0.05)$. Glucose levels were higher in the CN than the CB $24 \mathrm{~h}$ after colostrum administration $(116 \mathrm{mg} / \mathrm{dl}$ and $97 \mathrm{mg} / \mathrm{dl}$, respectively; $p<0.05)$. There were no diarrheas or respiratory illnesses in lambs from both groups at $24 \mathrm{~h}$ after birth $(p>0.05)$. Maybe, the use of bovine dehydrated colostrum transfers a similar immunization than natural colostrum, which generated a low incidence of respiratory and metabolic illnesses and a good body development.
\end{abstract}

Key words: Bovine dehydrated colostrum, Glucose, Immunoglobulins, Lamb, Refractometer, Weight gain.

\section{INTRODUCTION}

Ruminants, during the newborn stage, are considered as agammaglobulinemic (calves and buffalos) or hypogammaglobulinemic (lambs) (Castro et al., 2009), where the colostrum intake is important for the decrease of illness incidence, an adequate development and a low peripartum mortality (Castro et al., 2011). Serum immunoglobulin concentration in dairy cattle is an important indication of immunity against pathogenic microorganism (Bayram et al., 2016). However, colostrum quality and quantity that a lamb consumes can be affected by multiple factors. For example, pre partum undernutrition in the ewe can decrease the production and quality of the colostrum, it has been shown that a low nutrition before parturition can reduce the production of colostrum and milk (Banchero et al., 2015). The health status of animals also affects the quality of colostrum (Maunsell et al., 1998). This quality can be determined by direct radial immune-diffusion or indirect methods (Brix refractometer) (Yaylak et al., 2017). It is necessary to search for new ways of guaranteeing that lambs consume enough colostrum for them to acquire an adequate immunization, decrease the incidence of diseases and thus diminish a low body development. In this matter, research has been conducted for the use of bovine colostrum instead of ovine colostrum. Nonetheless, the management, storage, thawing process, quality, pasteurization and administration of colostrum may generate some issues when providing them to lambs. While pasteurization treatments can affect milk in several ways such as degradation of lactose (Wang et al., 2016). However, using dehydrated colostrum could
${ }^{1}$ Antonio Narro Autonomous Agrarian University, Periférico Raúl López Sánchez and Carretera a Santa Fe, Torreón, Coahuila, C.P. 27054, Mexico.

2Department of Pharmacology and Toxicology Faculty of Veterinary Medicine, UCM, Ciudad Universitaria s / n. 28040 Madrid, Spain.

${ }^{3}$ Technological Institute of Torreón, Torreón, Coahuila, Mexico.

Corresponding Author: Juan M. Guillén-Muñoz, Antonio Narro Autonomous Agrarian University, Periférico Raúl López Sánchez and Carretera a Santa Fe, Torreón, Coahuila, C.P. 27054, Mexico. Email: mvz_guillen@hotmail.com

How to cite this article: Arellano-Rodríguez, F., Lopez-Hernandez, J., Santos-Jiménez, Z., Ángel-Garcia, O., Carrillo-Moreno, D.I., Contreras-Villarreal, V., Gaytán-Alemán, L.R., Carrillo-Castellanos, E. and Guillén-Muñoz, J.M. (2022). Effect of Dehydrated Bovine Colostrum upon Immunity and Development of Dorper Lambs. Indian Journal of Animal Research. DOI: 10.18805/IJAR.BF-1446. Submitted: 30-09-2021 Accepted: 20-12-2021 Online: 11-01-2022

be a successful strategy in newborn lambs from twin births or from ewes with a low colostrum production. The present study evaluated, the use of bovine dehydrated colostrum as an alternative of natural ovine colostrum upon development and immunity in Dorper lambs.

\section{MATERIALS AND METHODS}

All methods and management of the experimental units used during this research were in strict accordance with ethics, care and animal welfare guidelines for research at an 
international (FASS, 2010) and national (NAM, 2010) level with institutional approval with reference number UAAANUL/38111-425501002-2706.

Study site and animal management: The study was done through November 4 to December 24, 2019, in northern Mexico, in the commercial farm "El Milagro" Ejido Granada, Matamoros, Coahuila de Zaragoza, Mexico, latitude of 25.3 $\mathrm{N}$, altitude of 1115 m.a.s.l). During the experimental period the pregnant ewes were fed, based on their nutritional requirements (NRC, 2007), twice daily (10:00 and 18:00 h) with the leftovers of the diet fed to dairy cattle $(17 \%$ PC y $1.5 \% \mathrm{E} \mathrm{M})$, they also had mineral salts and water ad libitum.

\section{Groups and treatments}

Forty multiparous ewes of Dorper breed, between 24 and 60 months old, a body condition score of 2.5 in a scale of $0-5(0=$ too thin and $5=$ too fat, with increases of 0.25 ; (Gallego-Calvo et al., 2014) with a mean body weight of $43.7 \pm 1.4 \mathrm{~kg}$. and pregnant during the last third of gestation were used. At lambing, 35 Dorper lambs that weighed higher than $3 \mathrm{~kg}$, born from natural birth, without dystocia, were selected. The lambs were randomly assigned to one of two groups, homogeneous regarding weight at birth $(3.4 \pm 0.3 \mathrm{~kg}$; Fig 1): $C N(n=17)$, fed with natural colostrum and, $C B(n=18)$, fed with bovine dehydrated colostrum. After $48 \mathrm{~h}$, all the lambs were allowed to feed from their mother until weening, which was at 21 days old.

\section{Lamb colostrum feeding management}

The process of natural suckling and artificial feeding was performed as follows: Lambs from the $\mathrm{CN}$ group received colostrum directly from their mothers, while lambs from the CB group were prevented from suckling from their mothers by placing a tape on the ewes nipples in order to prevent access to the udder during $24 \mathrm{~h}$. The amount of colostrum supplied was calculated in a rate of $10 \mathrm{~g}$ of dehydrated colostrum per every $\mathrm{kg}$ of weight. The dehydrated bovine colostrum was diluted in drinking water according to the products instructions and it was heated in a water bath at $40^{\circ} \mathrm{C}$ with a feeder bottle. After feeding, the lambs were left with their mothers, giving dehydrated colostrum feeds every
$6 \mathrm{~h}$. At $24 \mathrm{~h}$, tapes from the ewes nipples were removed in order to allow suckling from the lamb (Fig 1).

\section{Blood sampling}

Blood samples $(5 \mathrm{ml})$ were collected from each lamb (both lambs that received natural or dehydrated bovine colostrum) at birth and at $12 \mathrm{~h}$ and $24 \mathrm{~h}$ after birth. This was done through jugular venipuncture and collecting blood in tubes without anticoagulant (BD Vacutainer $\AA$ ). The samples were left to coagulate and placed in a cooler, the tubes were centrifuged at $3000 \mathrm{rpm}$ during $25 \mathrm{~min}$ at room temperature; afterwards, the plasma was stored at $-20^{\circ} \mathrm{C}$ until analyzed.

\section{Evaluated variables}

\section{Colostrum analysis}

Samples of natural colostrum (CN) were taken directly from the mothers nipple. The first flow of colostrum was discarded and, afterwards, $5 \mathrm{ml}$ from each nipple were collected in an sterilized vial and homogenized for further analysis. The bovine dehydrated colostrum (CB) was rehydrated following the manufacturer's instructions and was prepared, $10 \mathrm{ml}$ were taken for further analysis. Sampling of colostrum (CN and $\mathrm{CB}$ ) was done half an hour after parturition. The percentage of salts (SL \%), lipids (Lipids \%), protein (Protein $\%)$, crude protein (CP \%), solids (Solids \%), fat (Fat \%), as well as density $(\mathrm{kg} / \mathrm{m} 3)$ and temperature (Temperature \%) were determined with a milk analyzer (MÁSTER ECO, Milkotester). The standard calipers of the analyzer are for cow milk, ewe milk and ultra-pasteurized milk (UHT).

\section{Total proteins}

In order to determine the total proteins of colostrum at birth, $12 \mathrm{~h}$ and $24 \mathrm{~h}$ afterwards, a Brix [Atago PAL-1 (3810) Digital Hand-held Pocket Refractometer, 0.0-53.0\% Brix; Berge A.C., 2010], refractometer, calibrated according to the manufacturer's specifications and at room temperature, was used.

\section{Glucose levels}

From each sample, a drop of blood from the lambs was used in a glucometer (One Touch Select Plus $®$ ). The drop

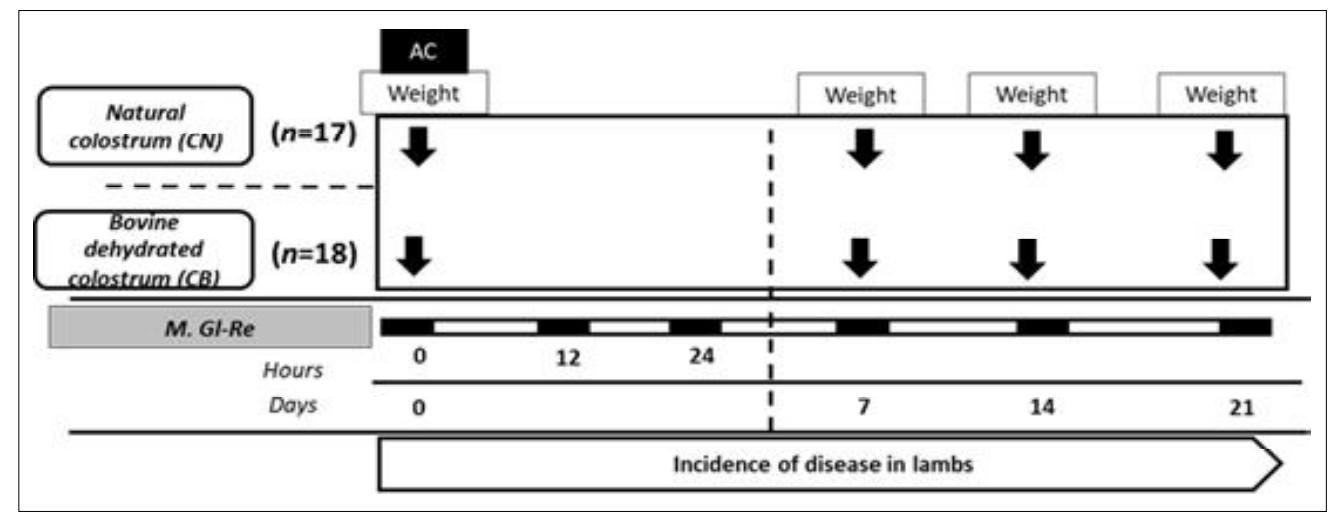

Fig 1: Variables evaluated for each treatment and time (hours/day) and that were registered from birth $(0 \mathrm{~h})$ until weening ( 21 days). Where: $\mathrm{M}$. $\mathrm{GI}-\mathrm{Re}=$ blood sampling for glucose and refractometer. $\mathrm{AC}=$ colostrum analysis. 
was placed in the reactive strip and further placed in the glucometer to obtain the result on screen $(\mathrm{mg} / \mathrm{dL})$; the samples were taken at parturition, 12 and $24 \mathrm{~h}$ postpartum and afterwards at 7, 14 and 21 days.

\section{Body weight and body gain}

The lambs weight was measured at birth and at 7,14 and 21 days, using a hanging digital scale (with a capacity of $450 \mathrm{~g}$ to $45 \mathrm{~kg}$; Salter Brecknell Electro Samson Crane Hanging Scale). In order to calculate the weight gain, weight at the registry day was subtracted from the previous weight.

\section{Illness incidence in the offspring}

Every health event was registered daily from birth to weening. The lambs' health was evaluated through a clinical exam performed by a veterinarian. For this, an anamnesis and clinical examination of lambs that showed depression, fever, anorexia or that showed a poor general condition was performed, this allowed the diagnosis of the condition involved (Radostitis et al., 2002). The considered illnesses were those that caused signs of diarrhea, respiratory problems and/or vesicular lesions (contagious ecthyma).

\section{Statistical analysis}

For the colostrum quality, body weight, weight gain, glucose and refractometry variables, an ANOVA was used to determine the effect between groups and interactions amongst them. Afterwards, a mean comparison t-test was used. The illness evaluation was analyzed with a chi-square. All statistical tests were performed with the statistical package SYSTAT 12.0 and were considered as significant when a difference of $p<0.05$ was found.

\section{RESULTS AND DISCUSSION}

\section{Colostrum analysis}

The values of lipids, CP, density, solids and fat, were higher for the $\mathrm{CN}$ compared to the CB $(p<0.05)$. In group $C N$, the $S L$ variable registered no statistical difference ( $p>0.05$; Fig 2). However, data from the colostrum analysis showed that colostrum from the $\mathrm{CN}$ group was better, due to the higher percentage of lipids, proteins, density and fat than those found in the CB group. In this matter, it has been reported that bovine colostrum has lower amounts of fat, CP and total solids (Hadjipanayiotou, 1995), which is related with a lower colostrum quality compared to ovine colostrum. One of the most important components of colostrum is the energy that it provides to the young through fat, lactose and total proteins (Alexander and Davies, 1959), which are absorbed in the young's intestines and are transformed to glucose, necessary for an adequate cellular metabolism (Nowak, 2006a). Even though the colostrum quality was different, lambs probably acquired the passive immunity because $C B$ is easy to assimilate, or because the minimal intake was assured, since it has been postulated that mothers, immediately after birth, separate from the birth site, thus, lambs need to feed rapidly in order to survive and stay near their mothers because they are their only food source (Nowak and Lindsay, 1990).

\section{Refractometry}

There were no statistical differences $(p>0.05)$ between the amount of total proteins from birth to the first $24 \mathrm{~h}$ after birth in the $\mathrm{CN}$ and $\mathrm{CB}$ groups. In average, both groups started with $6.2 \pm 0.1$ and ended in $8.9 \pm 0.2$ at $24 \mathrm{~h}$, while refractometry showed an increase across time during the first $12 \mathrm{~h}$ after birth in the $C N$ group $(p<0.05)$ and the $C B$

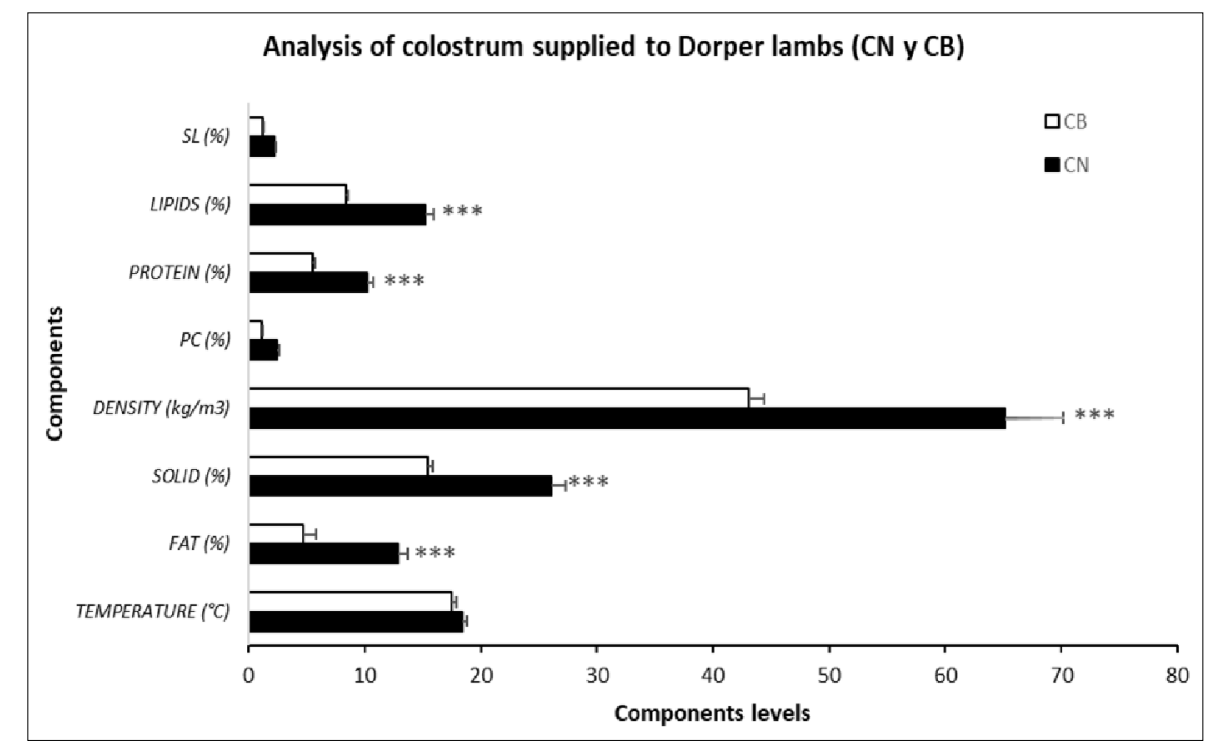

Fig 2: Variables from the colostrum analysis for each treatment:

$\mathrm{CN}$ (natural colostrum), CB (Bovine dehydrated colostrum). ${ }^{* \star *}$, statistically different $(p<0.001)$. 
group until $24 \mathrm{~h}$ after birth ( $\mathrm{p}<0.05$; Fig 3 ). Nonetheless, refractometry indicated that both groups had the same amount of total proteins, which probably indicates that the lambs acquired the same amount of immunoglobulins. In fact, no statistical difference was observed for the refractometric variable of both $\mathrm{CN}$ and $\mathrm{CB}$ groups. In this matter, it has been described that digital Brix refractometers can be a valuable tool to estimate the total protein concentration in ovine colostrum and lamb blood serum (Santiago et al., 2020). On the other hand, levels from both groups at birth and during the first $24 \mathrm{~h}$ after birth were similar, because, after 24 hours of birth, the process of passive absorption of immunoglobulins ends, which is known as "intestinal closure" (Nowak and Poindron, 2006).

\section{Glucose levels}

A higher level was observed in the $\mathrm{CN}$ group than for the CB group at $24 \mathrm{~h}$ after colostrum administration $(116 \mathrm{mg} / \mathrm{dl}$ and $97 \mathrm{mg} / \mathrm{dl}$, respectively; $\mathrm{p}<0.05$; Fig 4). Glucose levels at birth showed no significant differences between $\mathrm{CN}$ and CB (128 \pm 2.2 vs $124 \pm 2.8$, respectively; $p>0.05)$ from 7 to 21 $\mathrm{d}$ after birth, nonetheless, glucose level from each group

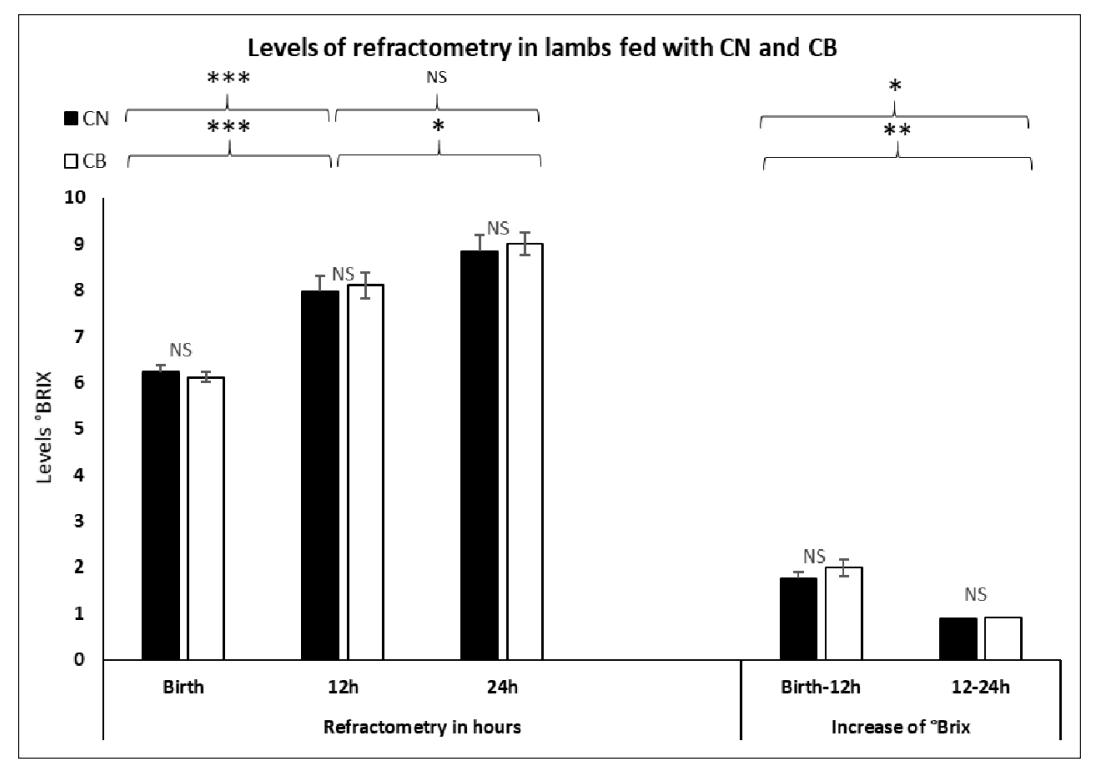

Fig 3: Refractometry ( $\left.{ }^{\circ} \mathrm{Brix}\right)$ values in lambs from birth to $24 \mathrm{~h}$ after birth for each treatment.

$\mathrm{CN}$ (natural colostrum), CB (bovine dehydrated colostrum). NS= non-significant. ${ }^{* *}$, statistically differ across time $(p<0.05)$. $* * *$, statistically differ across time $(p<0.001)$.

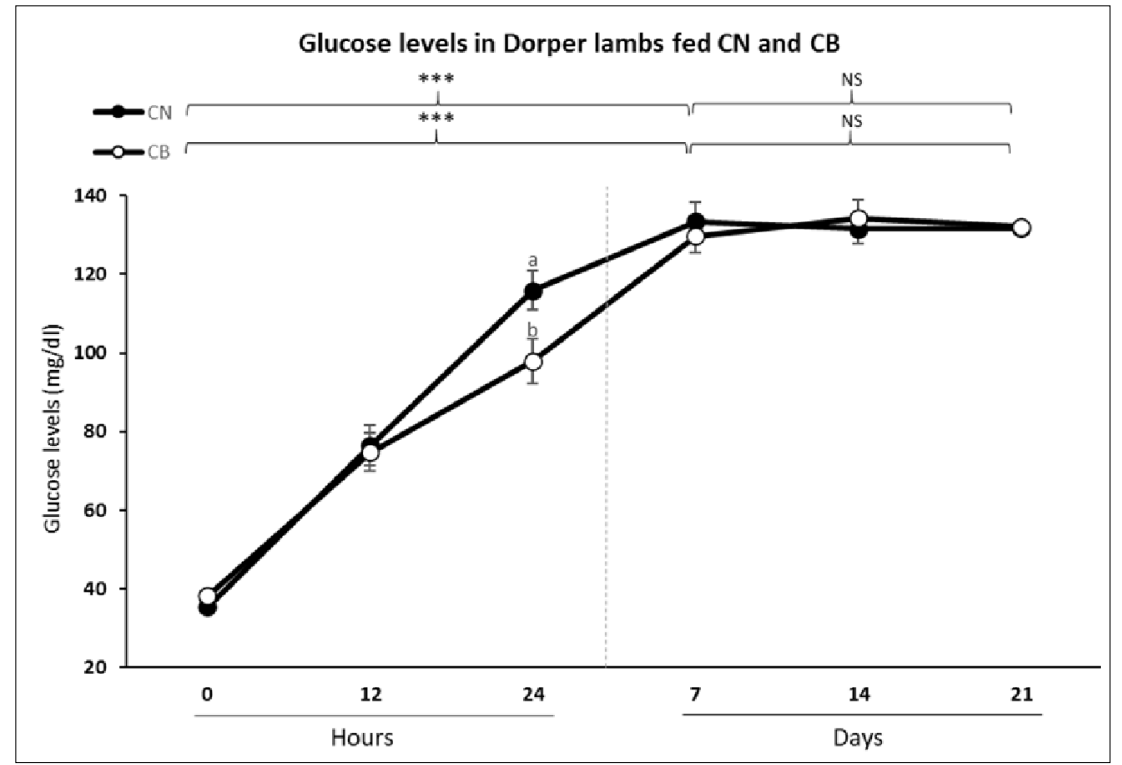

Fig 4: Blood glucose levels $(\mathrm{mg} / \mathrm{dl})$ from lambs fed with natural colostrum $(\mathrm{CN})$ and lambs fed with bovine dehydrated colostrum (CB) during the first $24 \mathrm{~h}$ of life and at 7,14 and 21 days old.

$a, b$, statistically differ between groups $(p<0.05)$. NS= non-significant. ${ }^{* *}$, statistically differ across time $(p<0.001)$. 
(CN and $\mathrm{CB}$ ) gradually increased across time from birth until 7 days afterwards $(p<0.001)$. From day 7 , levels remained similar $(p>0.05)$. In this sense, glucose levels were similar for both groups, both at birth and at $12 \mathrm{~h}$, but not at $24 \mathrm{~h}$, when the $\mathrm{CN}$ showed higher level. In fact, in our study, the offspring from both groups had around $40 \mathrm{mg} / \mathrm{dl}$ of blood glucose at birth and at $24 \mathrm{~h}$ after birth they reached a mean of $90 \mathrm{mg} / \mathrm{dl}$. This increase is associated to the first colostrum consumption, which indicates that animals from both groups consumed and adequate amount of colostrum, which, in line, provoked a gradual increase in blood glucose levels in the lambs. This is similar to the findings reported by Hammon et al. (2013).

\section{Weight and weight gain}

In Fig 5, results of body weight and daily weight gain are shown. There were no statistical differences $(p>0.05)$ between lamb weight from the $\mathrm{CN}$ and $\mathrm{CB}$ groups. At birth, in average both groups started in $4.3 \pm 0.3 \mathrm{~kg}$ and ended in $5.8 \pm 0.3 \mathrm{~kg}$. No statistical differences were found for weight gain $(2.4 \pm 0.3 \mathrm{Kg}$ for $\mathrm{CN}$ and $2.2 \pm 0.2 \mathrm{Kg}$ for $\mathrm{CB})$ during the 21 days after birth $(p>0.05)$. However, there was an effect across time for weight in each group from birth to $7 \mathrm{~d}$ after birth $(p>0.05)$ and from 14 to $21 d(p>0.001)$, but not for weight gain, which in average through the study was of 813 $\mathrm{g}$ for the CN group and $719 \mathrm{~g}$ for the CB group ( $>00.05)$. In the present study, it was observed that even when protein, fat and total solids values where lower for the $C B$ than the $\mathrm{CN}$ groups, this did not affect either body weight or weight gain of lambs, this probably was because the bovine and ovine colostrum used, which was only administered during the first hours after birth, was enough to cover the nutritional requirements as was mentioned before and after the consumption of the $\mathrm{CB}$, the lambs continued their feeding with their mother's milk. Thus, lambs had a similar development in both groups. Actually, when the lambs don't have enough energy, this affects the mother-lamb recognition, which hinders the adequate milk consumption because the lamb is not able to identify its mother (Nowak, 2006) and on the other hand, when the offspring don't acquire an adequate immunity, they are susceptible of a higher incidence of illnesses because they generate their own immunoglobulins until after 3 months of age (Banchero et al., 2015). Even though CB colostrum had a lower amount of total proteins than $\mathrm{CN}$ colostrum, lambs from thee $\mathrm{CB}$ group were guaranteed with a minimal supply $(8.1 \pm 0.2 \mathrm{~g} / \mathrm{kg}$ of the lambs body weight), since they were given two intakes before $12 \mathrm{~h}$ of life, while the other lambs first had to create the mother-lamb bond in order to access colostrum from their mother (Nowak and Poindron, 2006).

\section{IIIness incidence}

The number of sick lambs until 21 days old is shown in Fig 6 . Lambs from both groups had no diarrheas or respiratory illnesses during the first $24 \mathrm{~h}$ of life $(p>0.05)$. The lambs that were fed with $C B$ showed a higher incidence of contagious ecthyma ( $100 \%$ of contagions) compared to the $\mathrm{CN}$ group $(33 \% ; \mathrm{p}<0.05)$. The low incidence of respiratory and metabolic illnesses in the lambs from both groups suggests that, in fact, there was a good antibody absorption. It has been postulated that antibody absorption in new born ruminants determines their susceptibility to illnesses, with the consequent loss in development and high mortality rates, which was equal in both groups, which in line shows that

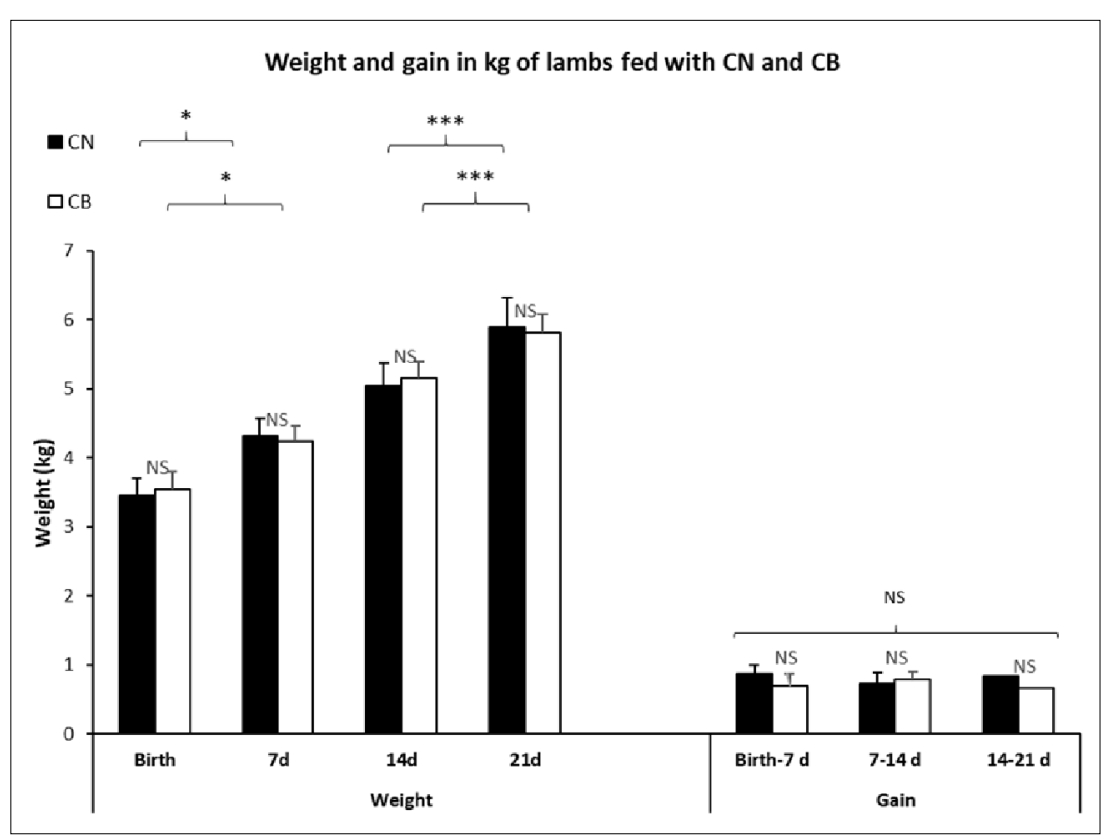

Fig 5: Body weight and weight gain $(\mathrm{kg})$ in lambs, from birth until weening for each treatment: $\mathrm{CN}$ (natural colostrum), CB (bovine dehydrated colostrum). NS = non-significant. ${ }^{*}$, statistically differ $(p<0.05) ;{ }^{* * *}$, statistically differ $(p<0.001)$. 


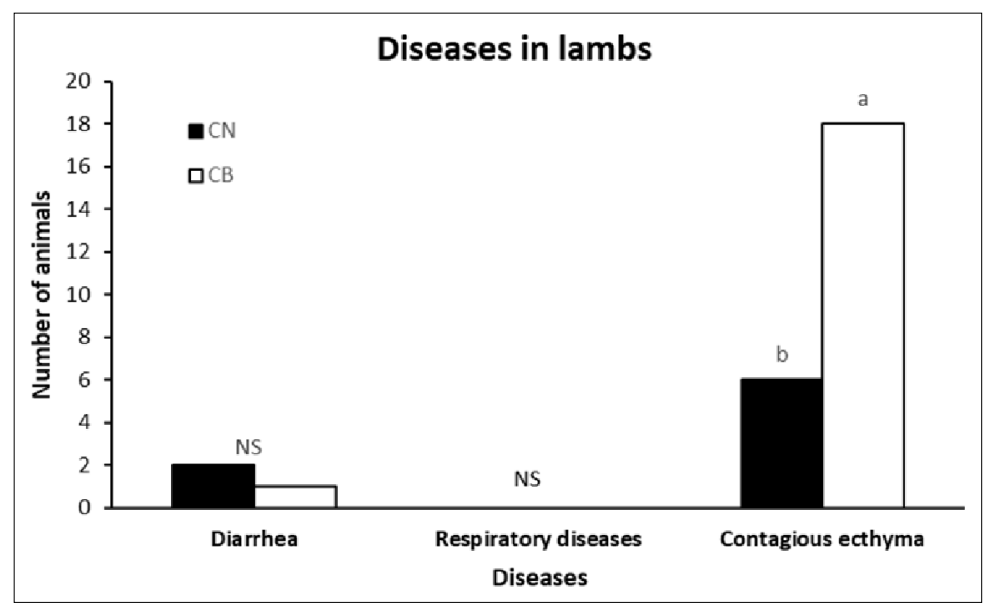

Fig 6: Number of sick lambs during the first 21 days after birth, $C N$ (natural colostrum), CB (bovine dehydrated colostrum). $a, b$, statistically differ between groups $(p<0.05)$. NS= non-significant.

there was a good immunization of lambs that consumed the bovine dehydrated colostrum (Machado-Neto et al.,2004). Moreover, there is evidence of transfer of high concentrations of IgG in new born small ruminants fed with natural bovine colostrum at $24 \mathrm{~h}$ of life (Moretti et al., 2010). If the $\lg$ transfer had been inadequate, lambs would have shown newborn infections during the first week of age, such as acute pneumonia, polyarthritis and diverse toxi-infections caused by clostridium. Also, they could have been infected with Escherichia, Staphylococcus, Corynebacterium, Pasteurella or Sphaerophorus (Lynch, 2013; Puppel et al., 2019), agents responsible of lamb deaths. In this sense, the CB could have also decreased the incidence of pneumonic and digestive diseases due to that it has lysosomes that act as germicides in almost every body fluid.

\section{CONCLUSION}

Based on our results, it may be concluded that the use of bovine dehydrated colostrum transferred immunization similar to natural ovine colostrum, which resulted in a low incidence of respiratory and metabolic diseases and a good body development.

\section{ACKNOWLEDGEMENT}

The authors thank to Jose M. Rodríguez-Gutierrez; Saskatoon Colostrum, Mexico S. de RL. de CV. for providing us with dehydrated colostrum for carrying out this research.

\section{REFERENCES}

Alexander, G. and Davies, H.L. (1959). Relationship of milk production to number of lambs born or suckled. Australian Journal of Agricultural Research. 10(5): 720-724.

Banchero, G.E., Milton, J.T.B., Lindsay, D.R., Martin, G.B. and Quintans, G. (2015). Colostrum production in ewes: A review of regulation mechanisms and of energy supply. Animal. 9(5): 831-837. https://doi.org/10.1017/S175173 1114003243.
Bayram, B., Aksakal, V., Turan, I., Demir, S., Mazlum, H. and Çosar, I. (2016). Comparison of immunoglobulin (IgG, IgM) concentrations in calves raised under organic and conventional conditions. Indian Journal of Animal Research. 50(6): 995-999. https://doi.org/10.18805/ijar.11472.

Castro, N., Capote, J., Bruckmaier, R.M. and Argüello, A. (2011). Management effects on colostrogenesis in small ruminants: A review. Journal of Applied Animal Research. 39(2): 8593. https://doi.org/10.1080/09712119.2011.581625.

Castro, N., Capote, J., Morales-De la nuez, A., Rodríguez, C. and Argüello, A. (2009). Effects of newborn characteristics and length of colostrum feeding period on passive immune transfer in goat kids. Journal of Dairy Science. 92(4): 1616-1619. https://doi.org/10.3168/jds.2008-1397.

FASS. (2010). Guide for the Care and Use of Agricultural Animals in Agricultural Research and Teaching, $3^{\text {rd }}$ ed.; Federation Animal Science Society: Champaing, IL, USA; p. 177.

Gallego-Calvo, L., Gatica, M.C., Guzmán, J.L. and Zarazaga, L.A. (2014). Role of body condition score and body weight in the control of seasonal reproduction in Blanca Andaluza goats. Animal Reproduction Science. 151(3-4): 157-163. https://doi.org/10.1016/j.anireprosci.2014.10.011.

Hadjipanayiotou, M. (1995). Composition of ewe, goat and cow milk and of colostrum of ewes and goats. Small Ruminant Research, 18(3): 255-262. https://doi.org/10.1016/09214488(95)00697-3.

Hammon, H.M., Steinhoff-Wagner, J., Flor, J., Schönhusen, U. and Metges, C.C. (2013). Lactation Biology Symposium: Role of colostrum and colostrum components on glucose metabolism in neonatal calves. Journal of Animal Science. 91(2): 685-695. https://doi.org/10.2527/jas.2012-5758.

Lynch, G.M. (2013) Efecto de la esquila preparto sobre la mortalidad neonatal en ovinos. http://repositoriodigital.uns.edu.ar/ handle/123456789/569.

Maunsell, F.P., Morin, D.E., Constable, P.D., Hurley, W.L., McCoy, G.C., Kakoma, I. and Isaacson, R.E. (1998). Effects of mastitis on the volume and composition of colostrum produced by Holstein cows. Journal of Dairy Science. 81(5): 1291-1299. 
Moretti, D.B., Kindlein, L., Pauletti, P., and Machado-Neto, R. (2010). IgG absorption by Santa Ines lambs fed Holstein bovine colostrum or Santa Ines ovine colostrum. Animal. 4(6): 933-937. doi.org/10.1017/S1751731110000157.

NAM. (2010). Guide for the Care and Use of Laboratory Animals, $1^{\text {st }}$ ed.; National Academy of Medicine: Harlan, Mexico City, Mexico.

Nowak, R. (2006). Suckling, milk and the development of preferences toward maternal cues by neonates: from early learning to filial attachment?. Advances in the Study of Behavior. 36: 1-58. https://doi.org/10.1016/S0065-3454(06)36001-9.

Nowak, R. and Poindron, P. (2006). From birth to colostrum: Early steps leading to Lamb survival. Reproduction Nutrition Development. 46(4): 431-446. https://doi.org/10.1051/ rnd:2006023

Nowak, R., Lindsay, D.R. (1990). Effect of genotype and litter size on discrimination of mothers by their twelve-hourold lambs. Behaviour. 115 (1-2): 1-13. https://doi.org/ $10.1163 / 156853990 \times 00266$.

NRC-National Research Council. (2007). Nutrient requirements of small ruminants: sheep, goats, cervids and new world camelids. Nutrient Requirements of Small Ruminants.
Puppel, K., Gołębiewski, M., Grodkowski, G., Slósarz, J., KunowskaSlósarz, M., Solarczyk, P. and Przysucha, T. (2019). Composition and factors affecting quality of bovine colostrum: A review. Animals. 9(12): 1070. https://doi.org/10.3390/ ani9121070

Radostits, O.M., Mayhew, I.G. and Houston, D. (2002). Examen y Diagnóstico Clínico en Veterinaria (No. V673 RADe).

Santiago, M.R., Fagundes, G.B., do Nascimento, D.M., Faustino, L.R., da Silva, C.M.G., Dias, F.E.F., de Souza, A.P., Arrivabene, M. and Cavalcante, T.V. (2020). Use of digital Brix refractometer to estimate total protein levels in Santa Inês ewes' colostrum and lambs' blood serum. Small Ruminant Research, 182, 78-80. doi.org/10.1016/ j.smallrumres.2019.10.014

Yaylak, E., Yavuz, M. and Özkaya, S. (2017). The effects of calving season and parity on colostrum quality of Holstein cows. Indian Journal of Animal Research. 51(3): 594-598. https:/ /doi.org/10.18805/ijar.11470

Wang, C., Zhu, Y. and Wang, J. (2016). Comparative study on the heat stability of goat milk and cow milk. Indian Journal of Animal Research. 50(4): 610-613. https://doi.org/ 10.18805/ijar.5961. 